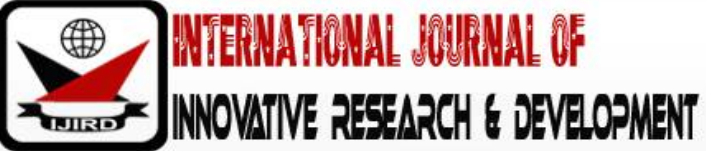

ISSN 2278 - 0211 (Online)

\section{Teachers' Content Knowledge of Early Childhood Care Development and Education Policy Documents and Pedagogical Skills: Implications for Preschoolers' Active Participation in Learning}

\begin{tabular}{c} 
Dr. IGE, O.0 \\
Lecturer, Department of Arts and Social Sciences Education, \\
University of Lagos, Akoka-Yaba Lagos, Nigeria \\
Usman-Abdulqadri T \\
Lecturer, Department of Early Childhood Care and Education, \\
Michael Otedola College of Primary Education, Nigeria \\
Salami, I. A. \\
Lecturer, Department of Early Childhood and Educational Foundation, \\
University of Ibadan, Nigeria \\
Ogunleye, T, 0. \\
Lecturer, Department of Primary Education, \\
Michael Otedola College of Primary Education, Nigeria \\
\hline
\end{tabular}

\begin{abstract}
:
Early years are the most important in the life cycle of every human being. Therefore, learning at this stage is optimal and the future of growing child relies on the quality of learning experiences that are logically and purposefully carried out by knowledgeable and skilled teachers. The study therefore investigated public teachers' content knowledge of ECCDE policy documents, pedagogical skills and the implications for preschoolers' active participation in learning. Correlation research design was used for the study. All teachers/caregivers in public preschools in Epe local government area of Lagos State, Southwest Nigeria constituted the population of the study. The sample comprised of eighty (80) preschool teachers/caregivers from fifty-one (51) public primary schools with linkage classes in the study area. Purposive sampling technique was used, based on the fact that, the study covers the entire target population. Two selfdesigned instruments were validated and used for data collection, which were Teachers' Content Knowledge of ECCDE Policy Documents Questionnaire (TCKEPDQ a=0.86) and Teachers' Pedagogical Skill /Preschoolers' Learning Participation Observation Schedule (TPSPLPOS $a=0.81$ ). Result showeda positive significant relationship between preschool teachers/caregivers' level of knowledge of ECCDE policy documents and their pedagogical skills. The study also revealed that most preschoolers were passive participants in learning processes due to teacher-centered approach employed. The study therefore recommends periodic training for preschool teachers/caregivers and regular monitoring of learning activities in public preschools.
\end{abstract}

Keywords: Content knowledge, ECCDE policy documents, pedagogical skills, active participation in learning

\section{Introduction}

It is no gainsaying the fact that almost every aspect of children's live today is different from that of last century's. In this century the need for children to learn only by memorizing facts is diminishing, we are in an era where children need to learn how to access and sieve information critical for any kernel of truth. Although, the basics of the 3Rs (reading, writing and arithmetic) will be continually needed by children and adults alike. But the fact remains that, one can not contemplate exactly what the adult world of today's children will be. This is why in addition to the 3Rs, children also need greater ability and dexterity to learn through multisensory approach in order to possess basic problem solving and critical thinking skills for them to be resilient in the face of ever changing society. Therefore, to meet learning needs of early years there is need for strong emphasis on the whole child. Because, learning during early childhood period is foundational and critical not only for school success but also for building future human capitals that will contribute meaningfully to the society. This was identified in Sustainable Development Goals (SDGs) 4 and 4.2 which specifically indicate 'Inclusive and quality education for all and promote lifelong learning through emphasis on early childhood education' (United Nations,2015). Typically, preschoolers' learning needs comprise but not limited to intellectual skills like; language, verbal, writing, numeracy and scientific; social skills such as; respect for others' view, life and property, respect for elders; 
spiritual skills like God's consciousness; emotional skills such as contentment, commitment, tolerance and others; physical skills such as fine and gross motor skills (Wilcox, Murphy, Bacon and Thomas, 2010).

Hence, the responsibility to fulfill learning needs of preschoolers rest on everyone who has a stake in their lives. In this study, caregivers' knowledge of early childhood care development and education (ECCDE) policy documents and pedagogical skills, the implications for preschoolers' active participation in learning serve as the focus of discussion.

This is why Nigeria government as the key stakeholder in actualizing quality education for all and promoting lifelong learning through emphasis on early childhood education had promulgated Laws, Acts, Policies and equally developed curricula to ensure integrative learning needs and full participation of preschoolers in learning activities. The following are some of the policy documents on ECCDE in Nigeria.

- $\quad$ National Policy on Education (NERDC,1977, 1981,1998, 2004 \& 2013);

- $\quad$ National Minimum Standard for Early Childcare Centres in Nigeria (NERDC, 2007);

- $\quad$ National Policy for Integrated Early Childhood Development in Nigeria (NERDC, 2007);

- Guidelines for Implementing National Policy on Integrated Early Childhood Development in Nigeria (FME, 2013);

- $\quad$ Early Childhood Development Standards for Nigeria (FME, 2013).

Besides the policy documents, curricula were produced. As far back as 1994 early childhood curriculum was produced for use in ECE centres. At the dawn of this century, came Millennium Development Goals (MDGs). To guarantee best care and support to young children in their most vulnerable period of life and subsequently lay a good foundation for early learning and holistic development. There was need for integrated curriculum for early years. Therefore, the federal government in collaboration with world development partners such as UNICEF produced integrated national curriculum for the education of children between the ages of 3 to 5 years plus. It was later reviewed to cover ages 0-5 years plus. This was published in 2007. Also in 2014 one-year pre-primary school curriculum was produced by the same bodies. This latest curriculum was meant to guide the implementation of the compulsory one-year pre-primary education. All these national policy documents and curricula are aimed at yielding the highest dividends and most sustainable gains for children, their families, communities and the nation at large.

In the year 2015, the Lagos State ministry of education reviewed the national early childhood curriculum and compiled the eight (8) themes of physical development; affective/psychosocial development; cognitive development and so on, in to eight (8) pre-school subjects which are arranged in to weekly teachable topics for the three terms in academic year to produce unified schemes of work for preschool classes. The subjects are: Physical and health education; social habits; letter work; number work; food and nutrition; health habits; basic science and technology, civic education and Yoruba language for kindergarten/pre-primary class (age 5-6) only. In 2018, the Lagos State early childhood care and education unified schemes of work was reviewed, in the latest edition physical and health education was changed to physical development and food and nutrition was expunged. In the curricula both at the national and Lagos state levels, the objectives, contents, performance activities both for caregivers and learners were clearly stated and learning activities were prescribed for every topic.

Despite all the aforementioned policy documents and value-laden curricula on integrated early childhood care and education that cater for holistic development with active participation of Nigerian children, vision of actualizing learning needs of early years in public preschools seems to be an illusion. This is not isolated from public preschool teachers' knowledge policy documents on ECCDE and their pedagogical competence. Most of these teachers were observed not employing age and developmentally appropriate pedagogy which might be as a result of inadequate knowledge of content of policy documents on ECCDE and preprimary education. Care giving in Nigeria is an all comers affair. It was observed that about $80 \%$ of caregivers in public ECCE centres were generally unqualified, they do not posses basic qualification and more than 50\% have no formal education (UNICEF Nigeria 2012). These categories of unqualified caregivers are doing opposite of policies, curricula contents and pedagogies. Although, it is an established fact, that the quality of teachers at any level determine the strength of educational system in meeting learning needs of learners in particular and societal goals in general. Ogah(2007) maintained that teacher is without contention, the pivot point around which the planned curriculum implementation revolves. In the same vein Snoek, Marco, Anja\& Marcel (2010) stated that, quality of teachers has a larger impact on the learning of children than the quality of planned curriculum.

Therefore, a plethora of policy documents on early years learning by Nigeria government is an indication of her readiness in providing quality early childhood learning for proper and better development and orientation of youngest citizens of Nigeria at their crucial and formative years of development. It is also quite obvious that the implementers of government policies in ECCDE through curriculum dissemination are the caregivers/teachers. Ideally, policy documents, curricula and guidelines for implementation are supposed to be readily available in pre-schools. The unfortunate thing is that these policy documents and curricula are not found in almost all the pre-schools in Nigeria. Hence, the robust learning experiences through active participation of preschoolers covered by the curricula are narrowed down to more teachers oriented and initiated learning. The non-availability of the national early childhood curriculum for ages 0-5 years in preschools has been confirmed in findings of researches in different states of the country (Viatonu, Usman-Abdulqadri \& Dagunduro 2011; Amali, Bello \&Okafor 2012; Okewole, Iluezi-Ogbedu, \&Osinowo, 2015).

Also of concern is the pedagogical skill of caregivers which has long been recognized in literature as an essential and veritable tool for fruitful learning (Abell, 2007). Caregivers' pedagogical competence contributes in boosting attainment of appreciable learning outcome of preschoolers. Studies have shown that pedagogical skills of the caregivers are indispensable in learning process of the early years. Teachers' knowledge of early years' learning needs and pedagogical competence are essential for effectiveness in teaching/learning processes. 
However, in a study conducted by Salami (2016), it was observed that instead of learner-centered pedagogical skill recommended in the national policy on education (2013) as learning strategy for preschoolers and simultaneous multisensory instruction approach (the combination of kinestics, vision and auditory) recommended in Lagos State early childhood care and education unified schemes of work 2015 and 2018, direct instruction ( teacher-centered) repeat-afterme, counting of numbers, letters of the alphabets and memorization of subjects matter are prominent. The broad aim of ECCDE and pre-primary education which centered on holistic development of the child is reduced only to prepare children for primary school. This teacher-centered pedagogy that is focused on attainment of lower order learning increase the tendency of non-attainment of national purpose of ECCDE. By so doing, shaky foundation for preschoolers at their formative years brings about permanent problem to educational system.

The common and obvious classroom pedagogical skills in public preschools in Epe Local government area of Lagos State, Nigeria are teacher-centered such as: whole class lecture method, rote learning, memorization, chorus answers, call and response. The learners are not allowed to freely explore the environment. Then the question is how would national purpose of ECCDE and pre-primary education be met with caregivers' dominated classrooms activity? This, among other problems, prompted the present study which attempted to examine preschool teachers' content knowledge of ECCDE policy documents and pedagogical competence: Implications for preschoolers' active participation in learning. Public ECCDE classes popularly known as linkage classes came in to existence in Nigeria in the year 2004 as a fall out of government decision to be fully involved in early childhood education. The linkage classes are to serve as feeder to the public primary schools which were experiencing low enrolment. With this remarkable intervention from government it is expected that public pre-schools should serve as models to privately owned preschools particularly the low-cost ones which are largest in number and appear to enroll the largest number of preschoolers in the country (Salami, 2016).

In reality however, it is saddening to note that quantum of public preschool teachers seems not to have adequate content knowledge of government policies on ECCDE and preprimary education, most equally adopt pedagogy of 'talk and chalk' where children are seen as passive listeners, the only time they are active is when they are on break. Learning activities were mainly through memorization and regurgitation of contents. Research evidence abounds from many scholars in the field of early childhood care development and education confirmed that learning needs of preschoolers include: 'hands on' experiences, toy/learning materials and games for manipulative and problem solving skills. Moreover, for preschoolers to become functioning members of the society they need support of teachers/caregivers in internal and social skills. Teachers/Caregivers need to help children develop positive self-concept for them to be happy, because joy and happiness suppose to be foundation of learning. But, joy has eroded average Nigerian preschoolers particularly those in public centres. This is as a result of the fact that, most public ECCDE centres lack knowledgeable and pedagogically skilled caregivers.

The passive learning process in Nigerian public pre-schools anchor by teachers with poor pedagogical skills hurt children's love for activity-based learning, squash their inborn desire to explore, experiment, investigate, measure and so on. This situation breeds children who are less creative, less curious and less capable of critical thinking and result to wasted creative talents.

The researchers are optimistic that the result of findings in the study would shed more light on whether or not the policy statements on quality service delivery for holistic development of Nigerian youngest citizens manifest in learning process in preschools. In the light of this, the following are the specific objectives of the study:

- To find out level of preschool teachers' knowledgeon major policy documents on ECCDE.

- To examine if preschool teachers adopt child-centered pedagogical skills.

- To investigate preschoolers' participation in learning activities

\section{Theoretical Background}

The position of this study is based on several models and theories related to teachers' knowledge and impact on pedagogical skills but specifically Cruickshank's model and Constructivism learning theory were adopted as the bases of discussion. The Cruickshank model (1985) is more of prior knowledge, classroom interaction and product of learning. This model was influenced by models created by Mitzel, Biddle, and Flanders. Mitzel contributed the concept of classifying variables in to triple P of Presage, Process and Product. Presage is the teacher's knowledge, level of experience and other teacher characteristics. Presage affect process and then, of course, process will in turn affect the product.

This model is related to this study in the sense that, the presage is likened to preschool teachers' content knowledge of ECCDE policy documents, the process is seen as the stage of employing pedagogical skills and preschoolers' active participation in learning as the product.

Constructivism also known as active learning theory was propounded by John Dewey. This theory is based on the belief that learning occurs when learners are actively involved in the process of learning. Constructivism belief knowledge is constructed or built up by learners as they connect actively with rich experiences (Santrock, 2004). This theory supports the argument that active participation of learners relies on pedagogical skills of teacher.

\subsection{The Following Research Questions Guide The Study}

- What is the level of preschool teachers' knowledge on major policy documents of ECCDE?

- Do preschool teachers adopt child-centered pedagogy?

- Are preschoolers actively participating in learning activities? 


\subsection{Research Hypotheses}

- $\mathrm{HO}_{1}$ : There is no significant relationship between preschool teachers' knowledge of major policy documents and their pedagogical sills.

- $\mathrm{H}_{2}$ : There is no significant relationship between preschool teachers' pedagogy skills and preschoolers' active participation in learning.

\section{Methodology}

Descriptive survey research design was used for the study. This was done in order to collect adequate and detailed information that describe the existing phenomenon, identify problem areas and justify relationship between preschoolers' active participation in learning, preschool teachers' awareness on major policy documents, their pedagogical skills and proffer solutions. All caregivers in public preschools in Epe local government area of LagosState, Southwest Nigeria constituted the population of the study. The sample comprised of eighty (80) preschool teachers from fifty-one public primary schools with linkage classes in the study area. Purposive sampling technique was used. Two self-designed instruments were validated and used for data collection, which were Teachers' Content Knowledge of ECCDE Policy Documents Questionnaire (TCKEPDQ a= 0.86) and Teachers' Pedagogical Skills/Preschoolers' Learning Participation Observation Schedule (TPSPLPOS a 0.81 ). The questionnaire was a five items Likert-type 4-points rating questionnaire on knowledge of preschool teachers on ECCDE policy documents. The scales of responses were abbreviated with its points thus: Extremely Aware $(E A)=4$, Moderately Aware $(M A)=3$, Slightly Aware $(S A)=2$, Not Aware (NA) =1 while the observation schedule elicits Teachers' Pedagogical Skill/Preschoolers' Participation in Learning

\subsection{Procedure for Data Collection}

With the help of colleagues during teaching practice supervision, the researchers administered the instrument to the subjects in their various preschools classrooms. All the eighty (80) copies of questionnaire and observation schedules were completely filled and retrieved from the respondents for analysis giving a $100 \%$ return rate. The instrument administration lasted for period of four (4) weeks.

\section{Results}

\begin{tabular}{|c|c|c|c|c|c|c|c|}
\hline $\mathbf{S} / \mathbf{N}$ & Items & $\begin{array}{c}\text { NA } \\
1\end{array}$ & $\begin{array}{c}\text { SA } \\
2\end{array}$ & $\begin{array}{c}\text { MA } \\
\mathbf{3}\end{array}$ & $\begin{array}{c}\text { EA } \\
4\end{array}$ & Mean & Std. D \\
\hline 1 & $\begin{array}{l}\text { I am aware that exploration of nature and } \\
\text { environment is one of the national purpose of } \\
\text { early childhood care and education }\end{array}$ & $\begin{array}{c}08 \\
(10)\end{array}$ & $\begin{array}{c}40 \\
(50)\end{array}$ & $\begin{array}{c}25 \\
(31.3)\end{array}$ & $\begin{array}{c}7 \\
(8.7)\end{array}$ & 2.39 & 0.61 \\
\hline 2 & $\begin{array}{c}\text { National Policy on Education recommends } \\
\text { preschoolers' active participation in learning. }\end{array}$ & $\begin{array}{c}18 \\
(22.5) \\
\end{array}$ & $\begin{array}{c}32 \\
(40)\end{array}$ & $\begin{array}{c}18 \\
(22.5) \\
\end{array}$ & $\begin{array}{c}12 \\
(15)\end{array}$ & 2.3 & 0.96 \\
\hline 3 & $\begin{array}{l}\text { I understand the concept of holistic development } \\
\text { as emphasized in national policy on integrated } \\
\text { early childhood development. }\end{array}$ & $\begin{array}{c}14 \\
(17.5)\end{array}$ & $\begin{array}{c}30 \\
(37.5)\end{array}$ & $\begin{array}{c}22 \\
(27.5)\end{array}$ & $\begin{array}{c}14 \\
(17.5)\end{array}$ & 2.45 & 0.95 \\
\hline 4 & $\begin{array}{c}\text { I am aware and conversant with the content of } \\
\text { the national early childhood education } \\
\text { curriculum. }\end{array}$ & $\begin{array}{c}27 \\
(33.8)\end{array}$ & $\begin{array}{c}24 \\
(30)\end{array}$ & $\begin{array}{c}19 \\
(23.7)\end{array}$ & $\begin{array}{c}10 \\
(12.5)\end{array}$ & 2.15 & 1.05 \\
\hline 5 & $\begin{array}{l}\text { I am aware of multisensory instruction approach } \\
\text { recommended in Lagos State unified schemes of } \\
\text { work for pre-primary classes. }\end{array}$ & $\begin{array}{c}15 \\
(18.8)\end{array}$ & $\begin{array}{c}27 \\
(33.7)\end{array}$ & $\begin{array}{c}20 \\
(25)\end{array}$ & $\begin{array}{c}18 \\
(22.5)\end{array}$ & 2.51 & 1.07 \\
\hline
\end{tabular}

Table 1: Preschool Teachers' Awareness on Major ECCDE/ Pre-Primary Policy

Documents and Pedagogical Skills

Aggregate Mean.........2.36

Table 1 above presents the result of Preschool Teachers' Content Knowledge of ECCDE/ Pre-primary Policy documents in Epe local government area of Lagos State - Nigeria. Technically, sentences 1, 3 and 5 can be seen to be best items measuring the Preschool Teachers' Knowledge of ECCDE Policy Documents because their mean values exceed the average criterion mean, while items 2 and 4 respectively falls below the criterion mean score. Descriptively item 1 , shows that $8.7 \%$ of respondents claimed to be extremely aware, $31.3 \%$ moderately aware, $50 \%$ slightly aware and only $10 \%$ of respondents admitted of not being aware that exploration of nature and environment is one of the national purpose of early childhood care and education; Meanwhile, 15\% of respondents extremely agreed with fact that National Policy on Education recommends preschoolers' active participation in learning, $22.5 \%$ moderately agreed, $40 \%$ slightly agreed while $22.5 \%$ did not agree. The table also depicts that $17.5 \%$ of respondents claimed extreme understanding of holistic development of the child as emphasized in national policy on integrated early childhood development, $27.5 \%$ moderately aware, 37.5 slightly aware, while $17.5 \%$ claimed ignorance of the concept. The result on the table shows that $12.5 \%$ of the respondents claimed to be extremely aware and conversant with the content of national early childhood education, $23.7 \%$ moderately aware, 30\% slightly aware while 33.8\% claimed not aware. Responses on multisensory instructional approach recommended in Lagos State unified schemes of work for pre-primary classes, result on the table shows that $22.5 \%$ of respondents claimed to be extremely aware, $25 \%$ moderately aware, $33.7 \%$ of respondents claimed to be slightly aware, while $18.8 \%$ claimed ignorance of the approach. 


\begin{tabular}{|c|c|c|c|c|c|}
\hline & Items & $\begin{array}{c}\text { Observed } \\
\text { (f) }\end{array}$ & \% & Not observed & \% \\
\hline 1 & $\begin{array}{c}\text { Children are observed to be actively } \\
\text { involved in the process of learning }\end{array}$ & 15 & $(18.7)$ & 65 & $(81.3)$ \\
\hline 2 & $\begin{array}{c}\text { Collaborative learning where children } \\
\text { actively interact by sharing experiences } \\
\text { and taking different roles is observed. }\end{array}$ & 07 & $(8.8)$ & 73 & $(91.2)$ \\
\hline 3 & $\begin{array}{c}\text { Different abilities of learners in } \\
\text { teaching/learning process based on the } \\
\text { principles of individual differences is taken } \\
\text { care of }\end{array}$ & 12 & $(15)$ & 68 & $(85)$ \\
\hline 4 & $\begin{array}{c}\text { Children are seen making observations, } \\
\text { investigating, measuring and asking } \\
\text { questions in an organized real life } \\
\text { situation. }\end{array}$ & 09 & $(11.3)$ & 71 & $(88.7)$ \\
\hline 5 & $\begin{array}{c}\text { Learning environment is rich with age } \\
\text { appropriate materials. }\end{array}$ & 07 & $(8.8)$ & 73 & $(91.2)$ \\
\hline
\end{tabular}

Table 2: Preschool Teachers' Pedagogical Skill and Preschoolers' Learning Participation

Table 2 above presents the result of Preschool Teachers' Pedagogical Skill/ Preschoolers' Learning Participation. Through the use of observation technique, the result revealed that only $18.7 \%$ of the classes were observed actively engaged children in learning process while in 65 classes representing $81.3 \%$ the learners were passive because teachers were observed telling the learners contents of lessons. This means that most teachers in public preschools cannot carry their duties out as supposed and thus is not in agreement with Fowowe and Mafikuyomi (2019) who asserted that preschool teachers should get preschoolers involved in learning so that they can think about what they have learnt in lots of different ways and apply it - not just at school but at home and on the street and so on. Similarly, with regards to collaborative learning insignificant $8.8 \%$ of the classes were seen allowing children interaction by sharing experiences and taking different roles while majority of the classes observed teachers served as knowledge dispenser in front of the whole class, the observed situation in the public preschools negates collaborative learning advocated for by Austin (2014) as one of the $21^{\text {st }}$ century learning skills. In the same vein, only $15 \%$ and $11.3 \%$ of the teachers allow different abilities of learners in a learning situation based on the principles of individual differences, employ observations, investigation as learning approaches in an organized real life situation respectively. Observations on age appropriate learning materials show only $8.8 \%$ of learning environment observed are rich with age appropriate materials and the absence of this deprived learners the much needed sensory experiences and this agrees with Klinert et al (2002) who asserted that without the provision of instructional materials children do not have access to effective learning which is essential to participation in teaching/learning processes.

\subsection{Presentation and Interpretation of Results}

The researchers collected the data and subjected it to Pearson Product Moment Correlation Coefficient a parametric statistics type in testing the formulated hypotheses. The result of the analysis is presented below:

$\mathrm{HO}_{1}$ : There is no significant relationship between preschool teachers' awareness on major ECCDE policy documents and their pedagogical skills.

\begin{tabular}{|c|c|c|c|c|c|c|}
\hline Variable & $\mathbf{N}$ & Mean & SD & r-value & Sig.(2-tailed) & Remark \\
\hline $\begin{array}{c}\text { Teachers level of } \\
\text { awareness }\end{array}$ & 80 & 39.87 & 2.96 & 0.85 & 0.067 & Significant \\
\hline $\begin{array}{c}\text { Pedagogical } \\
\text { Skills }\end{array}$ & 80 & 36.33 & 2.68 & & & \\
\hline
\end{tabular}

Table 3: Summary of Correlation Analysis Showing Relationship between Preschool

Teachers' Awareness on Major Policy Documents and Pedagogical Skills

Table 3 above shows a positive significant relationship between preschool teachers' awareness on major ECCDE policy documents and their pedagogical skill $(\mathrm{r}=0.85 ; \mathrm{p}<0.05)$ hence the null hypotheses is rejected., while the alternative which stipulates that there is a significant relationship between preschool teachers' awareness on major policy documents and pedagogical skills is rejected.

- $\mathrm{HO}_{2}$ : There is no significant relationship between preschool teachers' pedagogy skills and preschoolers' active participation in learning. 


\begin{tabular}{|c|c|c|c|c|c|c|}
\hline Variable & $\mathbf{N}$ & Mean & SD & r-value & Sig.(2-tailed) & Remark \\
\hline $\begin{array}{c}\text { Teachers level } \\
\text { of awareness }\end{array}$ & 80 & 37.41 & 2.75 & 0.723 & 0.041 & Significant \\
\hline $\begin{array}{c}\text { Pedagogical } \\
\text { Skills }\end{array}$ & 80 & 36.33 & 2.68 & & & \\
\hline
\end{tabular}

Table 4: Summary of Correlation Analysis Showing Relationship between Preschool Teachers' Pedagogy Skills and Preschoolers' Active Participation in Learning

Table 2 above shows a positive significant relationship preschool teacher pedagogical skills and preschooler' active participation in learning $\mathrm{r}$-value of 0.723 significant at 0.05 alpha level $(\mathrm{P}<0.05)$ hence the null hypotheses is rejected, while the alternative which stipulates that there is a significant relationship between preschool teachers' pedagogical skills and preschoolers' active participation in learning is retained.

\section{Discussion of Findings}

From hypotheses one, it revealed that there is no significant relationship between preschool teachers' awareness of major policy documents and preschoolers' active participation in learning. This findings conform with the work of Marcel (2010); Okewole, Iluezi-Ogbedu, \& Osinowo, (2015) who noted that despite all the aforementioned policy documents and value-laden curricula on integrated early childhood care and education that cater for holistic development with active participation of Nigerian children, the vision of actualizing learning needs of early years in public preschools seems to be an illusion. This is not isolated from public preschool teachers' knowledge on Nigerian policy documents on ECCDE as on a policy designed to meet specific needs of preschool learners in the society.

From hypotheses two, it was revealed that that there is a significant relationship between preschool teachers' pedagogical skills and preschoolers' active participation in learning. This finding is in consonance with that of Abell, (2007) who affirmed that caregivers' knowledge of pedagogical skills contributes in boosting attainment of appreciable learning outcome of preschoolers. Studies have shown that pedagogical skills of the caregivers are indispensable in learning process of the early years. Knowledge of early years' learning needs is important for caregivers to teach effectively only when these are accompanied with knowledge of how to teach youngest generation. Abell (2007) and Salami (2016) were also of the concern that the pedagogical skill of caregivers has long been recognized as an essential and veritable tool needed for fruitful learning, effective and efficient learning especially in a classroom situation.

\section{Conclusion}

Findings in the study show low awareness of preschool teacher son major ECCDE/ Pre-primary policy documents and this invariably led to teacher-centered approaches where learners were seen as absorbers of information instead of being active in learning processes. Based on the result from the study carried out it is not an exaggeration to say that the type of public preschool teachers found in the study area did not measure up with the demands of $21^{\text {st }}$ century pedagogical skills to equip today's children with knowledge and skills for the technological driven and challenging society.

\section{Recommendations}

The study recommends that:

- Periodic training such as seminar and workshops should be organized for preschool teachers in order to keep them abreast with $21^{\text {st }}$ century pedagogical skills.

- $\quad$ All ECCDE/ Pre-primary policy documents should be made available to pre-school teachers.

- Regular training should be organized for preschool teachers on knowledge of content and implementation of ECCDE/ Pre-primary policy documents.

- $\quad$ Recruitment process for preschool teachers should be devoid of any inadequacies as only certified and specialized teachers should be employed.

- Periodic monitoring and evaluation should be carried out on implementation of policies on ECCDE and preprimary education in order to ensure that the implementers of policies are doing the right thing so as to keep up with trends and development tied around early childhood education.

\section{References}

i. $\quad$ Abell, S. K. (2007). Research on science teacher knowledge. In S. K. Abell\& N. G. Lederman (Eds.).Handbook of Research on Science Education. Mahwah, NJ/London: Lawrence Erlbaum Associates.

ii. Amali, I. 0.0., Bello, M., \&Okafor I. P. (2012).An Assessment of Pre-Primary School Programme Activities in Kwara State, Nigeria. Journal of Education and Practice, 3(6), 100-105.

iii. Austin, C. (2014). The 21 $1^{\text {st }}$ Century Teacher. A Paper Delivered at a-day workshop for Teachers on $5^{\text {th }}$ April.

iv. Cruickshank, D. (1985). Profile of an effective teacher. Educational Horizons, 90-92

v. Federal Republic of Nigeria. (2013). National Policy on Education. Lagos, NERDC press.

vi. Fowowe, S.S. \& Mafikuyomi, J.A. (2019). Choose your Professional Caregiver Right and Learn Well. In E. Oduolowu, I.A. Salami \& M.D. Amosun (Eds.). Fundamentals of Pre-school and Primary School Teacher Preparation in Nigeria. Pp. 109-134. Ibadan: Department of Early Childhood and Educational Foundations.

vii. Kleinert, H., Garrett, B., Towles, E., Garrett, M., Nowak-Drabik, K., Waddell, C., Kearns, J. (2002). Alternate assessment scores and life outcomes for students with significant disabilities: Are they related? Assessment for Effective Intervention, 28, 19-30. doi:10.1177/073724770202800103 
viii. Lagos State Ministry of Education (2018).Unified Schemes of Work for Early Childhood care and Education.

ix. Ogah, E.U. (2007). Teacher Preparation and Management for Quality Instruction in Secondary Schools. Nigerian Journal of Curriculum Studies 14 (1) 50-59.

x. Okewole, J. O., Iluezi-Ogbedu, V. A., \& Osinowo O. A. (2015). An evaluation of the implementation of early childhood education curriculum in Osun State. Journal of Education and Practice, 6(4), 48-54. Retrieved from http://www.iiste.org/Journals/index.php/JEP/article/viewFile/19793/20357

xi. Salami, I.A., (2016). Nigerian Early Childhood Education Policies and Practices for Sustainability European Journal of Research and Reflections in Educational Sciences, 4(5), 71-85.

xii. Santrock, J.W. (2004). Educational Psychology New York: McGraw-Hill.

xiii. Snoek, Marco, Anja, Swennen\& Marcel van der Klink (2010). The Teacher Educator: A neglected factor in the contemporary debate on teacher education. In Brian Hudson, Pavelzgaga and Bjorn Astrand (Eds.), Advancing quality cultures for teacher education in Europe: Tensions and Opportunities. Umea School of Education, Umea University, Sweden, pp. 33-48 http://tepe.files.wordpress.com/2012/01/tepe_monograph_2010.p df accessed Nov. 2, 2012.UNICEF Nigeria, (2012). Monthly Situation Report. November, 2012.

xiv. Viatonu, O. A., Usman-Abdulqadri, T. \& Dagunduro, O. M. (2011).An Assessment of Implementation Strategies of Integrated Early Childcare and Development (IECD) in Epe Local Government Area of Lagos State. African Research Review, 5(4), 501-510.

xv. Wilcox, M. J., Murphy, K. M., Bacon, C.K.K., \& Thomas, S. (2010). Enhancing Children's language development of preschool classroom. Infant Child Research Programs. Arizona State University. Temple Arizona. Retrieved March 2012, from (http://crp.asu.edu. 